\title{
Modified ion exchange jackfruit seeds resin for removal of selected trace heavy metal ions from aqueous solution: Thermodynamic evaluation
}

\author{
Ndung'u S.N. ${ }^{*}$, Nthiga E.W. ${ }^{2}$, Wanjau R.N. ${ }^{1}$ \\ ${ }^{{ }^{*} 1}$ Department of Chemistry, Kenyatta University, P.O Box 43844-0100, Nairobi, Kenya. \\ ${ }^{2}$ Department of Chemistry, Dedan Kimathi University of Technology, P.O Box \\ 657-10100, Nyeri, Kenya. \\ ${ }^{1 *}$ Corresponding author's email: samuelndungu530@gmail.com
}

Received: 21 ${ }^{\text {st }}$ January 2021 / Accepted: 22nd May 2021 / Published online: 30th June 2021

\begin{abstract}
Water is essential for every life processes. However, its quality is deteriorating every day due to the recent industrial advancements. Anthropogenic processes such as industrialization, mining and agricultural activities have led to alarming discharge of heavy metal ions to the aquatic bodies. This possess a greater threat to human, animal and the entire ecosystem wellbeing. Accumulation of heavy metal ions in drinking water beyond permissible limits is detrimental to human health. Therefore, their removal is paramount. Conventional remediation techniques have been employed but have remained expensive and not universally appropriate. This has therefore spurred research interests in the use of adsorption techniques from locally available materials as an environmentally sustainable alternative. Jackfruit seeds are discarded as wastes of a Jackfruit and can be utilized as an ion exchange resin in heavy metal ions removal from wastewater. The present study involved application of previously prepared raw and modified Jackfruit seed resins to study thermodynamics of copper (II), lead (II) and cadmium (II) ions adsorption from synthetic water. FTIR results showed presence of functional groups in raw and modified resins as important sites for studying thermodynamics of adsorption of copper (II), lead (II) and cadmium (II) ions. Thermodynamic data showed that standard Gibb's free energy $\left(\Delta \mathrm{G}^{\circ}\right)$ values for all metals were negative indicating that adsorption process was feasible and favourable. Standard enthalpy change $\left(\Delta \mathrm{H}^{\circ}\right)$, standard entropy $\left(\Delta \mathrm{S}^{\circ}\right)$ and activation energy $\left(\mathrm{E}_{A}\right)$ were positive $\left(>40 \mathrm{~kJ} \mathrm{~mol}^{-1}\right)$ and in the order lead (II) $>$ copper (II) > cadmium (II). This confirmed adsorption
\end{abstract}

of copper (II), lead (II) and cadmium (II) ions onto both raw and modified resins was predominated by chemical interactions between the metal ions and the resin active sites. This was confirmed by very low values of sticking probability $\left(S^{*}\right)$. The findings indicated that ion exchange Jackfruit seeds resin is promising for heavy metal ions removal from wastewater in an optimized temperature controlled system.

Keywords: Jackfruit seeds, thermodynamics, ion exchange resin, chemisorption.

\section{INTRODUCTION}

With advanced rapid industrialization and technological advancements, industrial and agricultural activities have led to increased discharge of chemical pollutants to the environment (Chakraborty et al., 2015). Among these pollutants are different prevalent toxic heavy metals such as copper, lead and cadmium (O'Connell et al., 2008) which are released to water bodies through various industrial activities such as battery manufacturing, electroplating, petroleum refining, paper and pulp, ceramic and glass industries, pesticides and mining activities amongst others (Vijayaraghavan et al., 2016; Li et al., 2015; Biswas \& Mishra, 2015). This makes water unsafe for use thereby threatening all life processes (Saini et al., 2019). Their accumulation is of great concern because they have a long persistence, cannot biodegrade and are toxic even at their low concentrations in water. Their toxicity is by how they react with protein and enzyme ligands such as nitrogen 
$\left(-\mathrm{NH}_{2}\right.$ and $\left.>\mathrm{NH}\right)$, sulphur (-S-S-, $\left.-\mathrm{SH}\right)$ and oxygen (-COO, $\left.-\mathrm{OH},>\mathrm{C}=\mathrm{O},-\mathrm{OPO}_{3} \mathrm{H}\right)$ (Bathla \& Jain, 2016) in their biomolecules to form stable complexes which alter the body metabolism (Engwa et al., 2019; Kaile \& Nyirenda, 2016). This has led to various health effects associated with kidney damage, brain dysfunction, neonatal deaths, liver damage, reduced hemoglobin synthesis, cancer and death (Herrera et al., 2020; Liu et al., 2019; Khan et al., 2017). Maximum acceptable set levels of copper (II), lead (II) and cadmium (II) metal ions in drinking water are $2 \mathrm{mg} / \mathrm{L}$, $0.01 \mathrm{mg} / \mathrm{L}$ and $0.003 \mathrm{mg} / \mathrm{L}$ (WHO, 2011); $1 \mathrm{mg} / \mathrm{L}, 0.01$ $\mathrm{mg} / \mathrm{L}$ and $0.003 \mathrm{mg} / \mathrm{L}(\mathrm{KEBS}, 2007)$ and $2 \mathrm{mg} / \mathrm{L}, 0.01$ $\mathrm{mg} / \mathrm{L}$ and $0.005 \mathrm{mg} / \mathrm{L}(\mathrm{EU}, 1998)$. Therefore, treating industrial effluents before being discharged to water bodies becomes necessary.

A number of technologies such as chemical coagulation, reduction, electrodialysis, membrane technology, oxidation and chemical precipitation have been explored (Tovar et al., 2018) but have remained costly and inefficient. Adsorption has emerged an alternative technique due to its high efficiency even at trace levels, cost effectiveness and use of locally available materials (Gusain et al., 2014). The use of biomass from agricultural wastes in the removal of heavy metal ions has been reported (Nthiga et al., 2021; Ndung'u et al., 2020; Goyal \& Arora, 2016; Wanja et al., 2016; Omorogie et al., 2012). Use of biowaste in raw form has been reported to cause leaching of soluble organic compounds leading to high total oxygen demand (TOD), biological oxygen demand (BOD) and chemical oxygen demand (COD) in water (Abdolali et al., 2014). Therefore, to offer a solution to the above problem, biomass needs to be stabilized by chemical modification. The study focused on application of an ion exchange resin material that was prepared by chemically modifying Jackfruit seeds adsorbent with ethylenediamine (Ndung'u et al., 2020). The raw and modified resins were used to assess thermodynamics of copper (II), lead (II) and cadmium (II) ions adsorption from aqueous solutions.

\section{MATERIALS AND METHODS}

\section{Research Design}

The study aim was to use raw and modified ion exchange resin to study thermodynamics of adsorption of copper (II), lead (II) and cadmium (II) ions from aqueous solution using optimized parameters of $\mathrm{pH}$, time, speed, dose and initial concentration.

\section{Adsorbent preparation}

The fruits were collected locally from city park market, Nairobi Kenya and transported to Kenyatta University Chemistry laboratories, cleaned with distilled water and cut open to obtained seeds sample. The sample was cut to small pieces and oven dried at $105^{\circ} \mathrm{C}$ for 1 day to a constant weight. They were then ground into fine powder, sieved and kept in a tightly labelled bottle awaiting subsequent experiments. The raw resin was chemically modified as described by Ndung'u et al. (2020) and Da Silva Filho et al. (2006). The sixth carbon of the cellulose molecule of Jackfruit seeds adsorbent was chlorinated with thionyl chloride forming chlorodeoxy cellulose intermediary. Reaction mechanism is as shown by the figure 1 below:

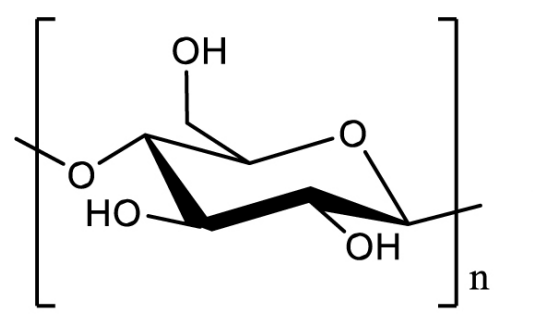

$+\mathrm{SOCl}_{2} \underset{\operatorname{Reflux}\left(80^{\circ} \mathrm{C}\right)}{\longrightarrow}$

Figure 1: Jackfruit seeds cellulose chlorination
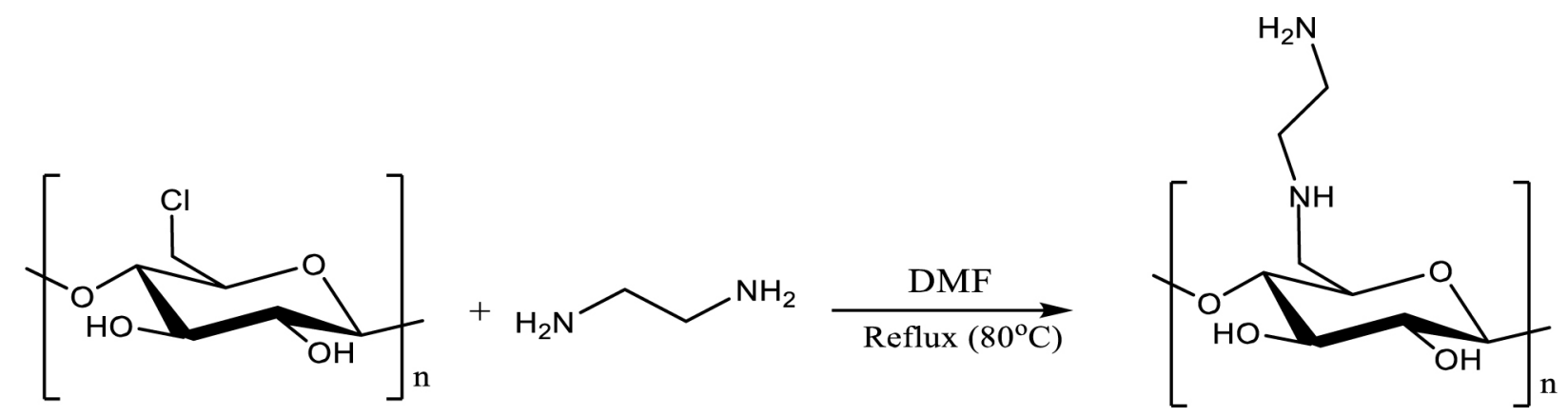

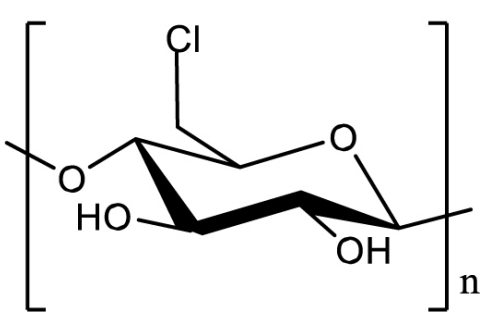

n

Figure 2: Modified Jackfruit seeds resin synthesis 
Chlorinated Jackfruit seeds cellulose was treated with ethylenediamine where chlorine substitution by nitrogen atom from the chelating ligand occurred as shown by the figure 2 above. The modified resin was vacuom dried and kept in a labelled bottle awaiting FTIR analysis and thermodynamic adsorption studies. The adsorbents (raw and modified) were characterized using Fourier Transform Infrared (FT-IR) spectrophotometer (IRTracer-100, SHIMADZU made in Japan).

\section{Adsorbate preparation}

$1000 \mathrm{mg} / \mathrm{L}$ of $\mathrm{Cu}\left(\mathrm{NO}_{3}\right)_{2}, \mathrm{~Pb}\left(\mathrm{NO}_{3}\right)_{2}$ and $\mathrm{Cd}\left(\mathrm{NO}_{3}\right)_{2}$ (anal grade) stock solutions were prepared by dissolving 2.952 $\mathrm{g}$ of $\mathrm{Cu}\left(\mathrm{NO}_{3}\right)_{2}, 1.599 \mathrm{~g} \mathrm{~Pb}\left(\mathrm{NO}_{3}\right)_{2}$ and $2.103 \mathrm{~g}$ of $\mathrm{Cd}$ $\left(\mathrm{NO}_{3}\right)_{2}$ in sodium acetate solution to maintain constant ionic strength. Concentrations of working solutions were prepared from the $1000 \mathrm{mg} / \mathrm{L}$ metal solutions by dilution. $0.1 \mathrm{M}$ of $\mathrm{HCl}$ and $\mathrm{KOH}$ were used for $\mathrm{pH}$ adjustments monitored by a calibrated $\mathrm{pH}$ meter (HANNA model).

\section{Metal analysis}

An atomic absorption spectrophotometer (AA-6200, SHIMADZU, Kyoto, Japan) instrument was used to determine the concentration of copper (II), lead (II) and cadmium (II) metal ions in the respective supernatant metal solutions.

\section{Thermodynamic experiments}

The experiments were conducted by batch mode in a temperature controlled water bath shaker using $120 \mathrm{~mL}$ plastic bottles. The experiments were performed by putting optimal dose of $15 \mathrm{mg}$ (raw) and $10 \mathrm{mg}$ (modified); $15 \mathrm{mg}$ (raw and modified); $13 \mathrm{mg}$ (raw) and $10 \mathrm{mg}$ (modified) to $20 \mathrm{~mL}$ of $30 \mathrm{mg} \mathrm{L}^{-1}$ optimal solutions of copper (II), lead (II) and cadmium (II) ions at optimal $\mathrm{pH}$ of 4.2 and 5.7; 5.0 and 6.4; 5.6 and 6.0 (raw and modified) respectively. Optimal agitation speed of $150 \mathrm{rpm}$ (both raw and modified) for both copper (II), lead (II) ions; 175 rpm (raw) and $150 \mathrm{rpm}$ (modified) for cadmium (II) ions. The mixtures were agitated at varying temperatures $(298 \mathrm{~K}$, $308 \mathrm{~K}, 318 \mathrm{~K}, 328 \mathrm{~K}$ and $338 \mathrm{~K}$ ) for 30 minutes at optimal agitation speeds of $150 \mathrm{rpm}$ for copper (II) and lead (II) ions; $175 \mathrm{rpm}$ (raw) and $150 \mathrm{rpm}$ (modified) for cadmium (II) ions. The mixture was filtered and the amount of residual metal ions in the solution was determined by AAS. The amount of copper (II), lead (II) and cadmium (II) ions adsorbed was calculated by equation 1 .

$$
\mathrm{q}_{\mathrm{e}}=\frac{\mathrm{C}_{\mathrm{i}}-\mathrm{C}_{\mathrm{e}}}{\mathrm{M}} \mathrm{V}
$$

where $q_{\theta}$ is the amount of cations adsorbed at equilibrium, $C_{i}$ is initial adsorbate concentration and $C_{\theta}$ is adsorbate final concentration of cations at equilibrium $(\mathrm{mg} / \mathrm{L}), \mathrm{V}$ is the total volume of Copper (II), Lead (II) and Cadmium (II) cations solution and $\mathrm{M}$ is the dosage mass (Ndung'u et al., 2020).

\section{Thermodynamic analysis}

To evaluate thermodynamic parameters, experimental data was analyzed by distribution coefficient $\left(\mathrm{K}_{\mathrm{d}}\right)$, calculation of Gibb's free energy $\left(\Delta \mathrm{G}^{\mathrm{a}}\right)$ and thermodynamic Van't Hoff equation (Moftakhar et al., 2016) given by equations $2-4$.

$$
\begin{aligned}
& \mathrm{k}_{\mathrm{d}}=\mathrm{q}_{\mathrm{e}} / \mathrm{c}_{\mathrm{e}} \\
& \Delta \mathrm{G}^{\circ}=-\mathrm{RT} \ln \mathrm{k}_{\mathrm{d}} \\
& \ln k_{d}=-\frac{\Delta \mathrm{H}^{\circ}}{\mathrm{RT}}+\frac{\Delta \mathrm{S}^{\circ}}{\mathrm{R}}
\end{aligned}
$$

where $\mathrm{k}_{\mathrm{d}}$ is the distribution coefficient; $\mathrm{q}_{e}$ is the amount of Copper (II), Lead (II) and Cadmium (II) cations complexed at equilibrium $\left(\mathrm{mg} \mathrm{g}^{-1}\right) . \mathrm{C}_{e}$ is the concentration of the residual cations at equilibrium ( $\mathrm{mg}$ $\left.\mathrm{L}^{-1}\right) ; \Delta \mathrm{G}^{\circ}$ is the Gibb's free energy $\left(\mathrm{J} \mathrm{mol}^{-1}\right) ; \Delta \mathrm{H}^{\circ}$ is the enthalpy change $\left(\mathrm{Jmol}^{-1}\right)$ and $\Delta \mathrm{S}^{\circ}$ is the entropy change $\left(\mathrm{J} \mathrm{mol}{ }^{-1} \mathrm{~K}^{-1}\right)$ at standard conditions of temperature and pressure, $\mathrm{T}$ is the absolute temperature $(\mathrm{K})$ and $\mathrm{R}$ is the Molar gas constant $\left(8.314 \mathrm{~J} \mathrm{~mol} / \mathrm{K}^{-1}\right)$. Van't Hoff plot of $\ln k_{d}$ verses reciprocal of temperature $(1 / \mathrm{T})$ yields a linear relationship with $\Delta \mathrm{H}^{\circ} / \mathrm{R}$ as the slope and $\Delta \mathrm{S}^{\circ} /_{\mathrm{R}}$ as the intercept which can be used to calculate $\Delta \mathrm{H}^{\circ}$ and $\Delta \mathrm{S}^{\circ}$ respectively.

The $\mathrm{E}_{A}$, activation energy and $S^{*}$, sticking probability can also be used to describe adsorption and can be calculated using Arrhenius equation (Ayawei et al., 2015) related to surface coverage $\theta$ as given in equations $5-7$.

$$
\theta=\left[1-\frac{\mathrm{c}_{\Theta}}{\mathrm{c}_{\mathrm{i}}}\right]
$$

$$
\mathrm{S}^{*}=(1-\theta) \mathrm{e}^{-\frac{\mathrm{E}_{\mathrm{g}}}{\mathrm{RT}}}
$$

$$
\ln (1-\theta)=\ln S^{*}+\frac{E_{A}}{R T}
$$

$S^{*}$ describes potentiality of adsorbed cations to remain on the binding sites in a temperature-controlled system (Sujata et al., 2014) and must lie in the range $0<S^{*}<$ 1. That is, if $S^{*}>1$, no adsorption, if $S^{*}=1$, a mixture of physi-adsorption and chemi-adsorption, if $S^{*}=0$, chemiadsorption predominates and if $0<S^{*}<1$ physi-adsorption predominates (Gongden et al., 2014). Negative activation 


\section{FTIR Results}

energy $\left(E_{A}\right)$ values indicate that the adsorption process is exothermic (David et al., 2015) and positive values dictate an endothermic process (Sujata et al., 2014). $\mathrm{E}_{A}$ dictates the nature of adsorption: 5-40 kJ/Mol shows physiadsorption and $40-800 \mathrm{~kJ} / \mathrm{Mol}$ shows that adsorption process is chemi-adsorption in nature (Heiba et al., 2018; Taha et al., 2016). A linear plot of $\ln (1-\Theta)$ against $1 / \mathrm{T}$ in Arrhenius equation yields a straight line with $\ln S^{*}$ as the intercept and $E_{A} / R_{R}$ as the slope used to calculate sticking probability $\left(S^{*}\right)$ and activation energy respectively.

\section{RESULTS AND DISCUSSIONS}

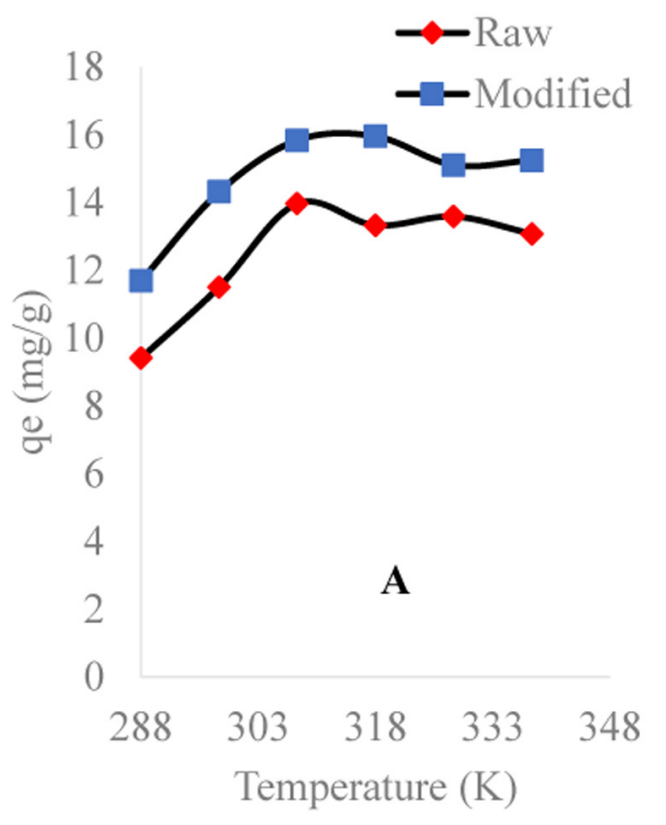

The FTIR spectrum of raw and modified resins (figure shown by Ndung'u et al., 2020) showed functional groups capable of binding to metal ions. The FTIR results showed presence of functional groups; hydroxyl $(-\mathrm{OH})$ at 3401.7 $\mathrm{cm}^{-1}$ (raw) and $3394.5 \mathrm{~cm}^{-1}$ (modified); carbonyl $(-\mathrm{C}=\mathrm{O})$ at $1651.0 \mathrm{~cm}^{-1}$ (raw) and $1665.2 \mathrm{~cm}^{-1}$ (modified) in ionic and non-ionic carboxylic (-COO-) acid derivatives and additional grafted amine groups $\left(-\mathrm{NH}_{2}\right)$ functional groups (shown by peaks at $1530.4 \mathrm{~cm}^{-1}$ and $656.5 \mathrm{~cm}^{-1}$ ) in modified resin as important active sites for studying thermodynamics of adsorption of copper (II), lead (II) and cadmium (II) ions.
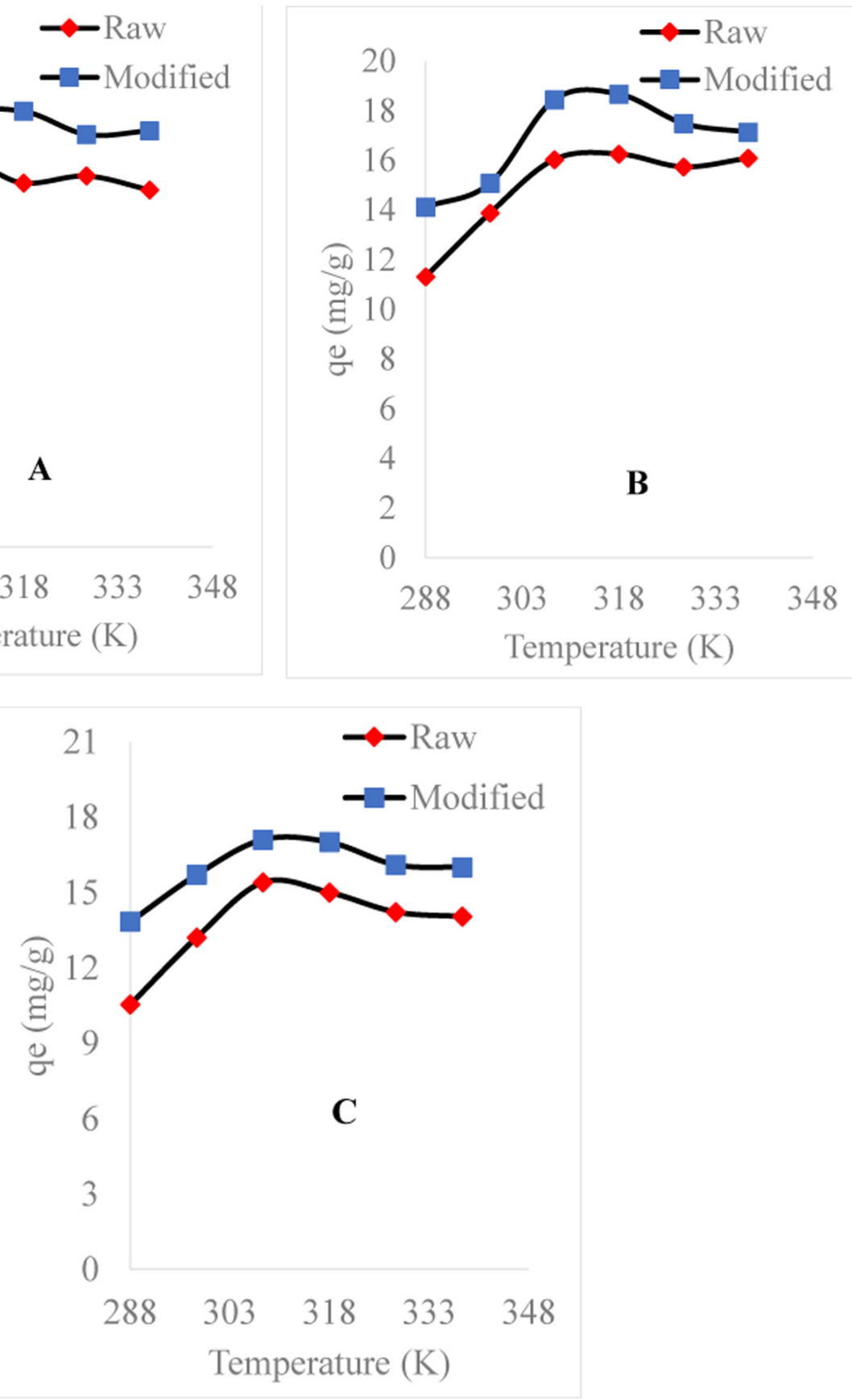

\section{Optimization}

\section{Effect of temperature}


The effect of temperature on the uptake of copper (II), lead (II) and cadmium (II) are shown by figure 3 .

Figure 3: A plot of qe $\left(\mathrm{mg} \mathrm{g}^{-1}\right)$ against temperature for adsorption of copper (II) (A), lead (II)

(B) and cadmium (II) (C) ions

The results presented in figure 3 show that increase in temperature increased adsorption capacity of the three metal ions from $288 \mathrm{~K}$ to $310 \mathrm{~K}$ with a maximum adsorption capacity of $13.97 \mathrm{mg} \mathrm{g}^{-1}$ (raw) and $15.96 \mathrm{mg} \mathrm{g}^{-1}$ (modified); $16.26 \mathrm{mg} \mathrm{g}^{-1}$ (raw) and $18.67 \mathrm{mg} \mathrm{g}^{-1}$ (modified); $15.41 \mathrm{mg} \mathrm{g}^{-1}$ (raw) and $17.11 \mathrm{mg} \mathrm{g}^{-1}$ (modified) for copper (II), lead (II) and cadmium (II) ions respectively beyond which a decrease was observed. The trend is expected for a chemisorption process which is mostly and endothermic adsorption process (Mustapha et al., 2019). Increase in adsorption capacity as temperature is increased from $298 \mathrm{~K}$ to $310 \mathrm{~K}$ is due to activation of resin surface sites and mobility of metals ions from the metal solution to the resin active sites (Huang et al., 2018; Rahman et al., 2015). A decrease in adsorption capacity at temperature beyond optimum is attributed by a decreased stability of metal ion-resin complex (Alinnor, 2007) which decreases the adsorption interaction forces between resin surface and the metal ions making the metal ions adsorbed to desorb from the resin surface (Nyoni et al., 2017). The results are coherent with those reported in the literature (Gaur et al., 2018; Nyoni et al., 2017).

\section{Thermodynamic results}

The results for $\Delta \mathrm{G}^{\circ}, \Delta \mathrm{H}^{\circ}, \Delta \mathrm{S}^{\circ}, \mathrm{S}^{*}$ and $\mathrm{E}_{A}$ were calculated from Van't Hoff and Arrhenius equations and are tabulated in Table 1.

Table 1: Thermodynamic parameters on copper (II), lead (II) and cadmium (II) ions adsorption

\begin{tabular}{|c|c|c|c|c|c|c|c|c|c|c|}
\hline \multirow[b]{2}{*}{ Metal ion } & \multirow[b]{2}{*}{ Resin } & \multicolumn{5}{|c|}{$\Delta G^{o}\left(\mathrm{KJ} \mathrm{mol}^{-1}\right)$ at different temperatures $(\mathrm{K})$} & \multirow[b]{2}{*}{$\begin{array}{c}\Delta \mathrm{H}^{\circ} \\
\mathrm{kJ} / \mathrm{mol}\end{array}$} & \multirow[b]{2}{*}{$\begin{array}{c}\Delta \mathrm{S}^{\circ} \\
\mathrm{J} \mathrm{mol} / \mathrm{K}\end{array}$} & \multirow[b]{2}{*}{$\mathrm{S}^{*}$} & \multirow[b]{2}{*}{$\begin{array}{c}\text { EA } \\
\mathrm{kJ} / \mathrm{mol}\end{array}$} \\
\hline & & 298 & 308 & 318 & 328 & 338 & & & & \\
\hline \multirow[t]{2}{*}{ Copper (II) } & Raw & -0.37 & -1.93 & -4.23 & -7.02 & -8.64 & 63.64 & 214.17 & $2.72 \times 10^{-09}$ & 50.33 \\
\hline & Modified & -1.66 & -3.76 & -5.11 & -8.26 & -13.38 & 79.87 & 271.45 & $1.62 \times 10^{-12}$ & 68.85 \\
\hline \multirow[t]{2}{*}{ Lead (II) } & Raw & -0.77 & -3.48 & -5.18 & -7.29 & -10.06 & 65.16 & 221.82 & $5.86 \times 10^{-10}$ & 53.74 \\
\hline & Modified & -3.99 & -7.92 & -11.54 & -14.16 & -16.33 & 87.89 & 310.44 & $9.75 \times 10^{-16}$ & 83.98 \\
\hline \multirow[t]{2}{*}{ Cadmium (II) } & Raw & -0.23 & -1.10 & -3.70 & -6.05 & -8.31 & 62.16 & 207.77 & $2.35 \times 10^{-08}$ & 45.43 \\
\hline & Modified & -1.43 & -3.10 & -4.14 & -7.75 & -10.99 & 68.40 & 232.29 & $3.65 \times 10^{-10}$ & 55.55 \\
\hline
\end{tabular}

Thermodynamic data showed that $\Delta \mathrm{G}^{\circ}$ values for the adsorption of cations were negative. This confirms the feasibility and spontaneity of adsorption of Copper (II), Lead (II) and Cadmium (II) ions (An et al., 2017). Van't Hoff and Arrhenius plots (Figure 4 and 5) shows positive values of $\Delta \mathrm{H}^{\circ}, \Delta \mathrm{S}^{\circ}$ and $\mathrm{E}_{A}$. Positive $\Delta \mathrm{H}^{\circ}$ values of $63.64 \mathrm{~kJ} / \mathrm{Mol}$ and $79.87 \mathrm{~kJ} / \mathrm{Mol}$ (copper (II)), $65.16 \mathrm{~kJ} / \mathrm{Mol}$ and $87.89 \mathrm{~kJ} / \mathrm{Mol}$ (lead (II)); $62.16 \mathrm{~kJ} / \mathrm{mol}$ and $68.40 \mathrm{~kJ} / \mathrm{Mol}$ (cadmium (II)) for raw and modified resins respectively are all above $+40 \mathrm{~kJ} / \mathrm{mol}$ dictating a chemisorption process. This is due to strong chemical

engagements between the metal ions and the resin surface (Ramdani et al., 2020). This was supported by positive $\mathrm{E}_{A}$ values of $50.33 \mathrm{~kJ} / \mathrm{Mol}$ and $68.85 \mathrm{~kJ} / \mathrm{Mol}$ (Copper (II)), $53.74 \mathrm{~kJ} / \mathrm{Mol}$ and $83.98 \mathrm{~kJ} / \mathrm{Mol}$ (lead (II)); $45.43 \mathrm{~kJ} / \mathrm{Mol}$ and $55.55 \mathrm{~kJ} / \mathrm{Mol}$ (cadmium (II)) for raw and modified resins and increase in negative $\Delta \mathrm{G}^{\circ}$ values with increase in temperature (Manzoor et al., 2019).

The order of $\Delta \mathrm{G}^{\circ}, \Delta \mathrm{H}^{\circ}$ and $\Delta \mathrm{S}^{\circ}$ values for the complexation of the three metal ions on both raw and modified resins was in the order $\mathrm{Pb}^{2+}>\mathrm{Cu}^{2+}>\mathrm{Cd}^{2+}$. This is due to the strong interaction between $\mathrm{Pb}^{2+}$ cations and the binding sites in both raw and modified resins and increased affinity to binding sites which require more $\Delta \mathrm{H}^{\circ}$ energy and major structural changes of the resin sites (higher values of $\Delta S^{\circ}$ ) (Ramdani et al., 2020) and this decreases in that order. The $\Delta S^{\circ}$ values were positive which reflected increased affinity of cations on raw and modified resin sites and increased disorderliness at the resin/metal solution interface with some structural changes in the surface resin that occurred during the complexation of the metal ions (Maleki et al., 

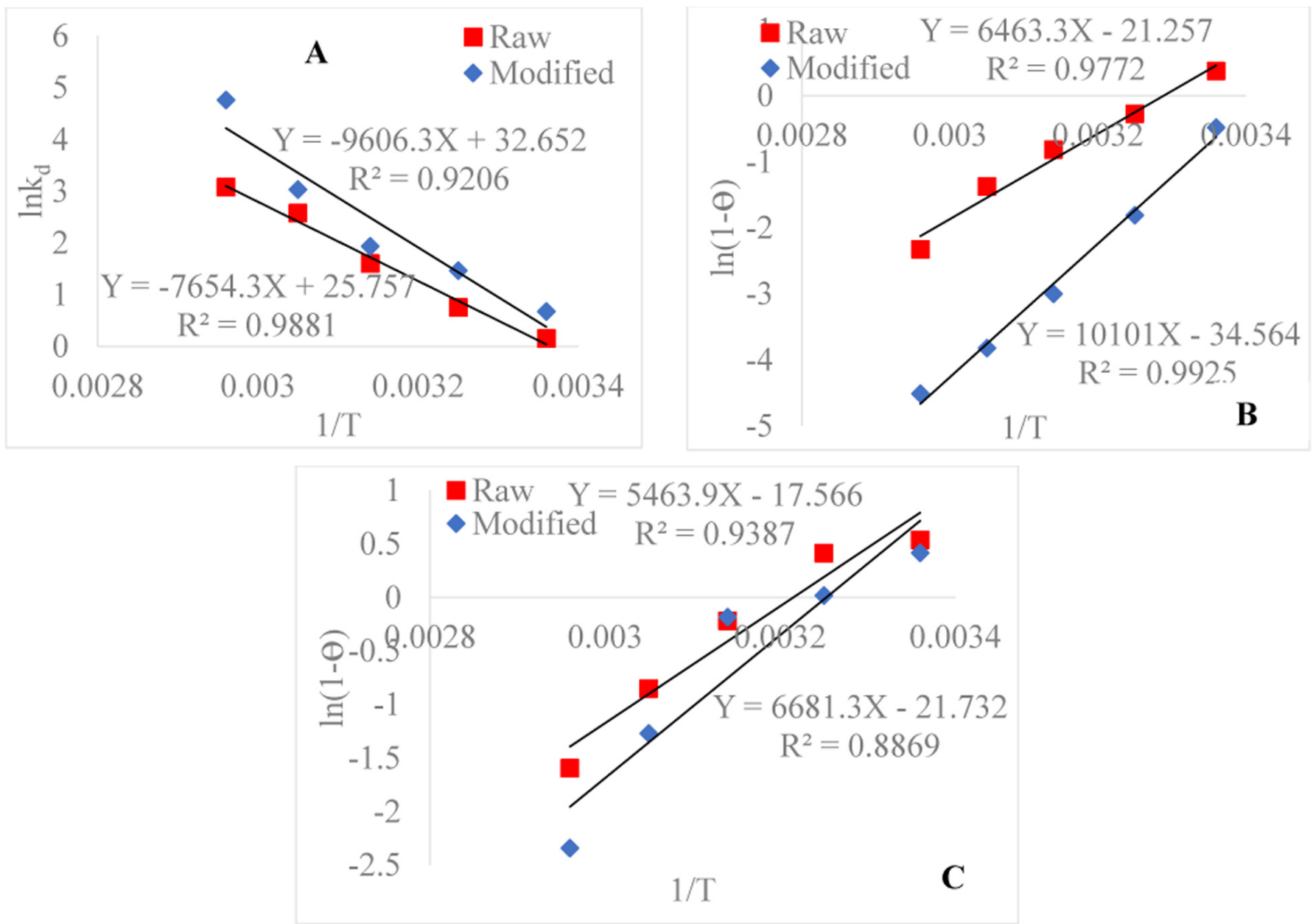

2015). Higher values of $\Delta \mathrm{G}^{\circ}, \Delta \mathrm{H}^{\circ}, \Delta \mathrm{S}^{\circ}$ and Ea were registered in modified form compared to raw form. Very low values of $\mathrm{S}^{*}$ close to zero showed a greater affinity of the complexed metal ions on both raw and modified resins dictating a
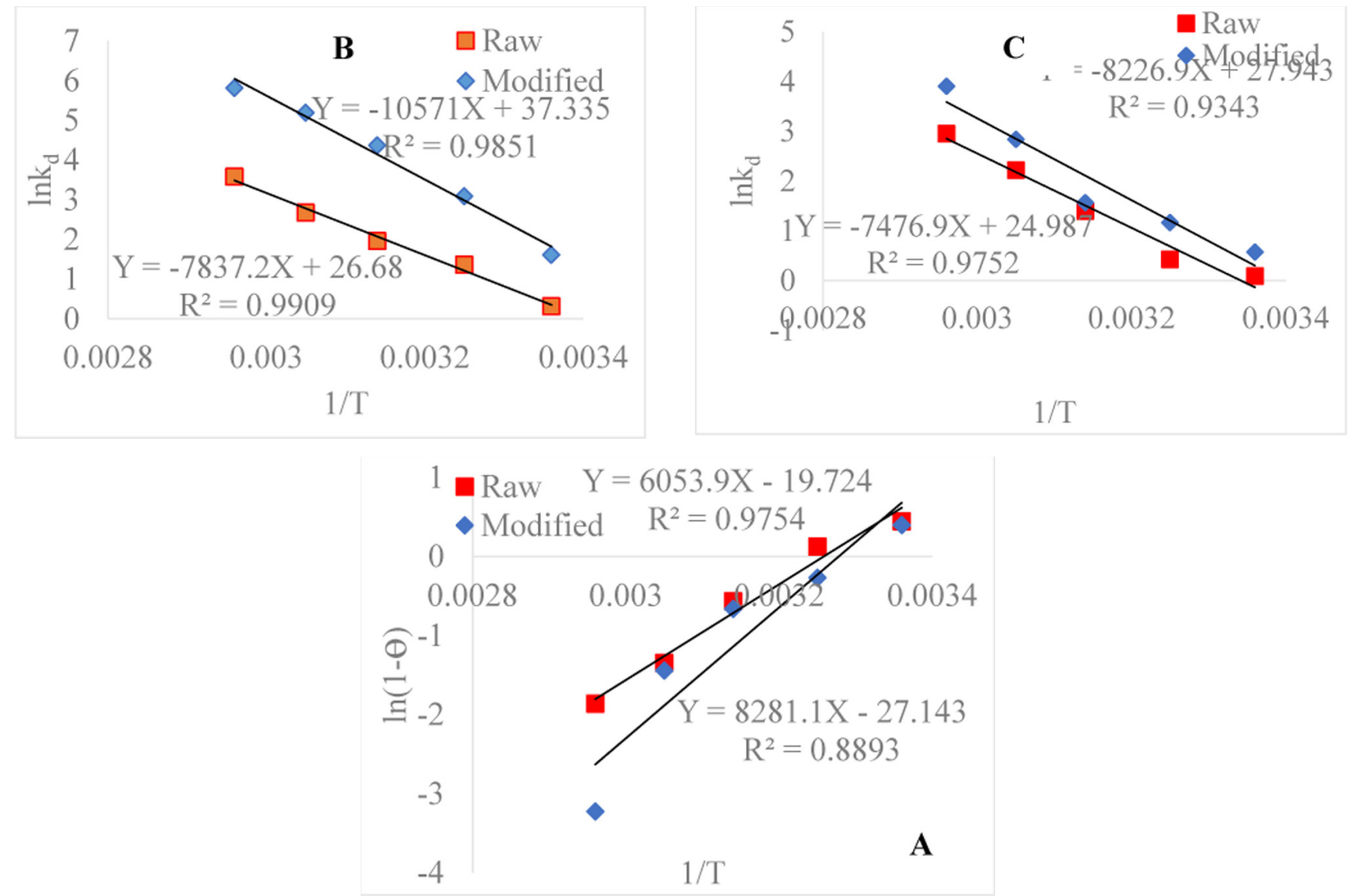

chemisorption process (Sujata et al., 2014) with modified forms registering more lower values than in raw form. The 
results for both raw and modified resins compare with those reported in the literature (Kumar et al., 2020; Sujata et al., 2014).

Figure 4: Van't Hoff plots of copper (II) (A), lead (II) (B) and cadmium (II) (C) ions respectively

Figure 5: Arrhenius plots of copper (II) (A), lead (II) (B) and cadmium (II) (C) ions respectively

\section{CONCLUSIONS}

In this study, thermodynamic interaction of Copper (II), Lead (II) and Cadmium (II) ions onto raw and modified Jackfruit seeds resin was investigated. The negative $\Delta \mathrm{G}^{\circ}$ values confirmed spontaneity and feasibility of the metal ions adsorption onto raw and modified resins. High positive values of $\Delta \mathrm{H}^{\circ}$ and $\mathrm{E}_{A}$ indicated that adsorption was endothermic and chemisorption process. This was confirmed by very low values of $S^{*}$. The findings of the study showed the potentiality of the Jackfruit seeds adsorbent to remove copper (II), lead (II) and cadmium (II) ions in a temperature controlled system.

\section{ACKNOWLEDGEMENTS}

The authors are thankful to Kenyatta University for laboratory space, chemicals and equipment.

\section{CONFLICT OF INTEREST}

Authors declared no potential conflicts of interest regarding the research, authorship and/or publication of this manuscript.

\section{REFERENCES}

Abdolali, A., Guo, W. S., Ngo, H. H., Chen, S. S., Nguyen, N. C., \& Tung, K. L. (2014). Typical lignocellulosic wastes and by-products for biosorption process in water and wastewater treatment: A critical review. Bioresource Technology, 160, 57-66.

Alinnor, I. J. (2007). Adsorption of heavy metal ions from aqueous solution by fly ash. Fuel, 86(5-6), 853-857.

An, F. Q., Wu, R. Y., Li, M., Hu, T. P., Gao, J. F., \& Yuan, Z. G. (2017). Adsorption of heavy metal ions by iminodiacetic acid functionalized D301 resin: Kinetics, isotherms and thermodynamics. Reactive and Functional Polymers, 118, 42-50.

Ayawei, N., Godwin, J., \& Wankasi, D. (2015). Synthesis and sorption studies of the degradation of Congo Red by $\mathrm{Ni}$-Fe layered double hydroxide. International Journal of Applied Chemical Sciences Research, 13(3), 1197-1217.

Bathla, S., \& Jain, T. (2016). Heavy metals toxicity. International Journal of Health Sciences and Research, 6(5), 361-368.
Biswas, S., \& Mishra, U. (2015). Continuous fixed-bed column study and adsorption modeling: removal of lead ion from aqueous solution by charcoal originated from chemical carbonization of rubber wood sawdust. Journal of Chemistry, 2015, 1-9.

Chakraborty, S., Chakraborty, P., \& Nath, B. N. (2015). Lead distribution in coastal and estuarine sediments around India. Marine Pollution Bulletin, 97(1-2), 3646.

David, N., Dixon, E., Donbembe, W., \& Lucky, S. (2015). Synthesis, morphology and lead ion adsorption properties of metal organic frameworks of copper and cobalt. Chemical Sciences Journal, 6(4), 1-9.

Engwa, G. A., Ferdinand, P. U., Nwalo, F. N., \& Unachukwu, M. N. (2019). Mechanism and health effects of heavy metal toxicity in humans. Intechopen, $1-23$.

European Union. (1998). Council directive 98/83/EC on the quality of water intended for human consumption. Official Journal of the European Communities, 330, 3254.

Gaur, N., Kukreja, A., Yadav, M., \& Tiwari, A. (2018). Adsorptive removal of lead and arsenic from aqueous solution using soya bean as a novel biosorbent: equilibrium isotherm and thermal stability studies. Applied Water Science, 8(4), 98-109.

Gongden, J., Lohdip, Y., \& Nnebedum, J. (2014). Kinetic, equilibrium and thermodynamic assessment of the adsorption of cadmium using water lily (Nymphaea ampla) root biomass. Journal of Physical Sciences and Environmental Safety, 4(1), 33-50.

Goyal, K., \& Arora, S. (2016). Equilibrium and kinetic studies of adsorption of lead using low cost adsorbents. Indian Journal of Science and Technology, 9(44), 1-6.

Gusain, D., Srivastava, V., \& Sharma, Y. C. (2014). Kinetic and thermodynamic studies on the removal of $\mathrm{Cu}$ (II) ions from aqueous solutions by adsorption on modified sand. Journal of Industrial and Engineering Chemistry, 20(3), 841-847.

Heiba, H. F., Taha, A. A., Mostafa, A. R., Mohamed, L. A., \& Fahmy, M. A. (2018). Synthesis and characterization of CMC/MMT nanocomposite for $\mathrm{Cu}^{2+}$ sequestration in wastewater treatment. Korean Journal of Chemical Engineering, 35(9), 1844-1853.

Herrera, A., Tejada-Tovar, C., \& González-Delgado, Á. D. (2020). Enhancement of cadmium adsorption capacities of agricultural residues and industrial fruit byproducts by the incorporation of $\mathrm{Al}_{2} \mathrm{O}_{3}$ nanoparticles. ACS Omega, 5(37), 23645-23653.

Huang, Q., Zhao, J., Liu, M., Chen, J., Zhu, X., Wu, T., Tian, J., Yuanqing Wen, Y., Xiaoyong Zhang, X., \& Wei, Y. (2018). Preparation of polyethylene polyamine@tannic acid encapsulated MgAl-layered 
double hydroxide for the efficient removal of copper (II) ions from aqueous solution. Journal of the Taiwan Institute of Chemical Engineers, 82, 92-101.

Kaile, B., \& Nyirenda, J. (2016). Assessing the bio accumulative impact of four heavy metals on the endocrine system of Tilapia rendalli fish species in the Kafue river. Annual Research \& Review in Biology, 9(4), $1-23$.

Kenya Bureau of Standards (2007). Drinking waterspecification, Part 1: The requirements for drinking water. (3 ${ }^{\text {rd }}$ Edition), Nairobi: KEBS. (KS 459-1:2007).

Khan, T., Mustafa, M. R. U., Isa, M. H., Manan, T. S. B. A., Ho, Y. C., Lim, J. W., \& Yusof, N. Z. (2017). Artificial Neural Network (ANN) for modelling adsorption of lead ( $\mathrm{Pb}$ (II)) from aqueous solution. Water, Air, \& Soil Pollution, 228(11), 426-440.

Kumar, R., Sharma, H., Vishwakarma, M. C., Joshi, S. K., Bhandari, N. S., \& Kandpal, N. D. (2020). Adsorptive removal of $\mathrm{Pb}$ (II), $\mathrm{Cu}$ (II) and $\mathrm{Cd}$ (II) ions onto Rubus ellipticus as low-cost biosorbent. Asian Journal of Chemistry, 32(3), 495-500.

Li, W. C., Law, F. Y., \& Chan, Y. H. M. (2015). Biosorption studies on copper (II) and cadmium (II) using pretreated rice straw and rice husk. Environmental Science and Pollution Research, 24(10), 8903-8915.

Liu, F., Zhou, K., Chen, Q., Wang, A., \& Chen, W. (2018). Application of magnetic ferrite nanoparticles for removal of $\mathrm{Cu}$ (II) from copper-ammonia wastewater. Journal of Alloys and Compounds, 773, 140-149.

Maleki, A., Pajootan, E., \& Hayati, B. (2015). Ethyl acrylate grafted chitosan for heavy metal removal from wastewater: equilibrium, kinetic and thermodynamic studies. Journal of the Taiwan Institute of Chemical Engineers, 51, 127-134.

Manzoor, K., Ahmad, M., Ahmad, S., \& Ikram, S. (2019). Synthesis, characterization, kinetics, and thermodynamics of EDTA modified chitosancarboxymethyl cellulose as $\mathrm{Cu}$ (II) Ion adsorbent. ACS Omega, 4(17), 17425-17437.

Moftakhar, M. K., Yaftian, M. R., \& Ghorbanloo, M. (2016). Adsorption efficiency, thermodynamics and kinetics of schiff base-modified nanoparticles for removal of heavy metals. International Journal of Environmental Science and Technology, 13(7), 17071722.

Mustapha, S., Shuaib, D. T., Ndamitso, M. M., Etsuyankpa, M. B., Sumaila, A., Mohammed, U. M., \& Nasirudeen, M. B. (2019). Adsorption isotherm, kinetic and thermodynamic studies for the removal of $\mathrm{Pb}$ (II), $\mathrm{Cd}$ (II), $\mathrm{Zn}$ (II) and $\mathrm{Cu}$ (II) ions from aqueous solutions using Albizia lebbeck pods. Applied Water Science, 9(6), 142-152.

Naushad, M., ALOthman, Z. A., Awual, M. R., Alam,
M. M., \& Eldesoky, G. E. (2015). Adsorption kinetics, isotherms, and thermodynamic studies for the adsorption of $\mathrm{Pb}^{2+}$ and $\mathrm{Hg}^{2+}$ metal ions from aqueous medium using Ti (IV) iodovanadate cation exchanger. Ionics, 21(8), 2237-2245.

Ndung'u, S. N., Wanjau, R. N., Nthiga, E. W., Ndiritu, J., \& Mbugua, G. W. (2020). Complexation equilibrium studies of $\mathrm{Cu}^{2+}, \mathrm{Cd}^{2+}$ and $\mathrm{Pb}^{2+}$ ions onto ethylenediamine quaternised Artocarpus heterophyllus L. seeds from aqueous solution. IOSR Journal of Applied Chemistry (IOSR-JAC), 13(12), 01-12.

Nthiga, E. W., Ndung'u, S. N., Kibet, K., \& Wanjau, R. N. (2021). Removal of $\mathrm{Cr}^{3+}$ ions from a model solution by $\mathrm{HCl}$ treated Artocarpus heterophyllus L. seeds: equilibrium and kinetic study. International Journal of Research and Innovation in Applied Science, 6(2), 38-45.

Nyoni, S., Satiya, E., Mukaratirwa-Muchanyereyi, N., $\&$ Shumba, M. (2017). Comparative biosorption of $\mathrm{Pb}^{2+}$ ions from aqueous solution using Moringa oleifera plant parts: equilibrium, kinetics and thermodynamic studies. African Journal of Biotechnology, 16(48), 22152231.

O'Connell, D. W., Birkinshaw, C., \& O’Dwyer, T. F. (2008). Heavy metal adsorbents prepared from the modification of cellulose: A review. Bioresource Technology, 99(15), 6709-6724.

Omorogie, M. O., Babalola, J. O., Unuabonah, E. I., \& Gong, J. R. (2012). Kinetics and thermodynamics of heavy metal ions sequestration onto novel Nauclea diderrichii seed biomass. Bioresource Technology, 118, 576-579.

Rahman, M. S., \& Sathasivam, K. V. (2015). Heavy metal adsorption onto Kappaphycu spp. from aqueous solutions: The use of error functions for validation of isotherm and kinetics models. BioMed Research International, 2015, 1-13.

Ramdani, A., Kadechea, A., Adjdirb, M., Taleb, Z., Ikhoua, D., Taleb, S., \& Deratani, A. (2020). Lead and cadmium removal by adsorption process using hydroxyapatite porous materials. Water Practice and Technology, 15(1), 130-141.

Saini, S., Katnoria, J. K., \& Kaur, I. (2019). A comparative study for removal of cadmium (II) ions using unmodified and NTA-modified Dendrocalamus strictus charcoal powder. Journal of Environmental Health Science and Engineering, 17(1), 259-272.

Sujata, K., Singh, D., Mishra A., Upadhyay, M., \& Kumar, S. (2014). Red mud as adsorbent to remove lead (II) from aqueous solutions. Research Journal of Recent Sciences, 3(7), 18-27.

Taha, A. A., Shreadah, M. A., Ahmed, A. M., \& Heiba, H. F. (2016). Multi-component adsorption of $\mathrm{Pb}$ (II), Cd (II), and Ni (II) onto Egyptian Na-activated 
bentonite; equilibrium, kinetics, thermodynamics, and application for seawater desalination. Journal of Environmental Chemical Engineering, 4(1), 1166-1180.

Tovar, C. T., Ortiz, A. V., Correa, D. A., Gómez, N. P., \& Amor, M. O. (2018). Lead (II) remotion in solution using lemon peel (Citrus limonum) modified with citric acid. International Journal of Engineering and Technology, 10(1), 117-122.

Vijayaraghavan, K., Rangabhashiyam, S., Ashokkumar, T., \& Arockiaraj, J. (2016). Mono- and multi-component biosorption of lead (II), cadmium (II), copper (II) and nickel (II) ions onto coco-peat biomass. Separation Science and Technology, 51(17), 2725-2733.

Wanja, N. E., Murungi, J., Ali, A. H., \& Wanjau, R. (2016). Efficacy of adsorption of $\mathrm{Cu}$ (II), $\mathrm{Pb}$ (II) and Cd (II) Ions onto acid activated watermelon peels biomass from water. International Journal of Science and Research, 5(8), 671-679.

World Health Organization (2011). Guidelines for drinking-water quality (4 $4^{\text {th }}$ Edition). Malta: Gutenberg. ISBN 9789241548151. 